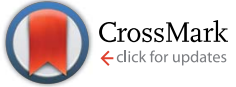

Cite this: RSC Adv., 2015, 5, 30989

Received 28th November 2014

Accepted 10th March 2015

DOI: $10.1039 / \mathrm{c} 4 \mathrm{ra15453c}$

www.rsc.org/advances

\title{
(Un)suitability of the use of pH buffers in biological, biochemical and environmental studies and their interaction with metal ions - a review $\uparrow$
}

\author{
Carlos M. H. Ferreira, ${ }^{a}$ Isabel S. S. Pinto, ${ }^{a}$ Eduardo V. Soares ${ }^{\text {bc }}$ \\ and Helena M. V. M. Soares ${ }^{\star a}$
}

\begin{abstract}
The use of buffers to maintain the $\mathrm{pH}$ within a desired range is a very common practice in chemical, biochemical and biological studies. Among them, zwitterionic $N$-substituted aminosulfonic acids, usually known as Good's buffers, although widely used, can complex metals and interact with biological systems. The present work reviews, discusses and updates the metal complexation characteristics of thirty one commercially available buffers. In addition, their impact on biological systems is also presented. The influences of these buffers on the results obtained in biological, biochemical and environmental studies, with special focus on their interaction with metal ions, are highlighted and critically reviewed. Using chemical speciation simulations, based on the current knowledge of the metal-buffer stability constants, a proposal of the most adequate buffer to employ for a given metal ion is presented.
\end{abstract}

\section{Introduction}

The proper maintenance of the $\mathrm{pH}$ is very important in several chemical, biochemical and biological applications. The $\mathrm{pH}$ affects the rate of chemical reactions, the efficiency of chemical separations, and the recovery and purity of products. Results given by analytical techniques, such as electrophoresis, chromatography, voltammetry and immunoassays, also depend on the control of the hydrogen ion concentration. In biological studies, the $\mathrm{pH}$ influences cell metabolism.

Proteins may suffer changes in their shape in response to modification of the $\mathrm{pH}$ of the surrounding solution. This effect can be explained due to the presence of carboxyl and amine functional groups, whose level of ionization is influenced by the $\mathrm{pH}$ of the solution. Thus, the changes of $\mathrm{pH}$ modify electrostatic interactions between charged functional groups of the amino acids and consequently the three-dimensional structure (shape) of the protein. Since the function of a protein is dependent on its shape, a deep change of $\mathrm{pH}$ can lead to the disruption of protein structure (denaturation) and loss of its function.

${ }^{a}$ REQUIMTE/LAQV, Department of Chemical Engineering, Faculty of Engineering, University of Porto, Rua Dr. Roberto Frias, 4200-465, Porto, Portugal. E-mail: hsoares@fe.up.pt; Fax: +351-225081449; Tel: +351-225081650

${ }^{b}$ Bioengineering Laboratory, Chemical Engineering Department, ISEP-School of Engineering of Polytechnic Institute of Porto, Porto, Portugal

'IBB-Institute for Biotechnology and Bioengineering, Centre for Biological Engineering, University of Minho, Braga, Portugal

$\dagger$ Electronic supplementary information (ESI) available. See DOI: $10.1039 / \mathrm{c} 4 \mathrm{ra} 15453 \mathrm{c}$
In a similar way, the $\mathrm{pH}$ affects enzymatic rates. This aspect is of particular importance, since during enzymatic reactions protons may be consumed or released. Thus, it is very important to maintain the proton concentration in solution without interference with the enzymes. A constant hydrogen concentration is also important in speciation studies in water. As an example, Wang et al. ${ }^{1}$ have demonstrated the importance of different factors, including $\mathrm{pH}$, on speciation and availability of aluminium in public water.

In a general way, the control of the $\mathrm{pH}$ is achieved by adding an appropriate buffer to the system, according to the desired $\mathrm{pH}$ range. However, buffers can affect biological systems at an organism or a biochemical level. For instance, the buffer can influence cell growth, ${ }^{2}$ modify lipid membrane interaction ${ }^{3}$ and enzyme activity (see below) and form radical species. ${ }^{4}$ The influence of specific buffers in different cellular and metabolic processes is detailed in subsections 3.1.1.-3.1.3.

Traditional buffers such as phosphate, citrate, borate and succinate have some disadvantages when they are used in biological or complex systems. Phosphate has a poor buffering capacity above $\mathrm{pH} 7.5$ and is an active participant in many biochemical processes. Phosphate inhibits carboxypeptidase, fumarase, urease, many kinases and dehydrogenases as well as enzymes with phosphate esters as substrates. ${ }^{5}$ Phosphates also demonstrate complexing capabilities with polyvalent cations and can therefore inhibit a series of metal ion-dependent biochemical reactions. ${ }^{6}$ Citrate and succinate form complexes with various cations. ${ }^{6}$ Imidazole is used to prepare buffers in the pH range of 6.2-7.8 at $25{ }^{\circ} \mathrm{C}$ and is also a chelator of various divalent cations. ${ }^{6}$ Tris is 
not a very efficient buffer below $\mathrm{pH} 7.5$ and displays a potentially reactive primary amine, which often acts as an inhibitor. It has an appreciable solubility in organic solvents; this property allows it to penetrate in biological membranes ${ }^{7}$ and form complexes with several metal ions. ${ }^{8}$ Tris is toxic for many mammalian cells due to its ability to penetrate into cells. ${ }^{9}$ Glycylglycine is an expensive buffer that only works well above pH 8.0 and complexes with cations. Borate buffer complexes with a wide variety of important respiratory metabolites and other organic compounds as well. ${ }^{7}$ In addition, many side effects cannot be predicted and buffers may uncouple or inhibit or modify reactions by mechanisms not yet understood.

In 1966, Good and co-workers ${ }^{10}$ proposed twelve pH buffers to be used in biological studies in substitution of the traditional ones. Eight more buffers were proposed in subsequent studies. ${ }^{6,11}$ Their proposal was based on the following criteria:

(1) buffers should cover $\mathbf{p H}$ values between 6 and 8 , since this is the $\mathrm{pH}$ region where fewer buffers were available and most biological reactions take place;

(2) buffers should have maximum water solubility to allow the use of concentrated stock solutions and minimum lipid solubility, making them impermeable to membranes;

(3) a minimal influence of the temperature, ionic strength or buffer concentration on the $\mathbf{p} \boldsymbol{K}_{\mathbf{a}}$ should occur;

(4) buffers should not form complexes with cations, or, if they do, the complexes should be soluble and the binding constants known;

(5) the buffers should be stable, not metabolized and should not act as enzyme inhibitors or substrate analogues;

(6) they should not absorb light above $240 \mathrm{~nm}$, and particularly not in any region that would be used in spectrophotometric assays;

(7) finally, they should be easy to prepare and inexpensive.

Zwitterionic $\mathrm{N}$-substituted aminosulfonic acids seemed to meet most of the criteria. These compounds, which are neutral molecules with a positive and a negative electrical charge, have advantages over the traditional buffers, especially due to the membrane impermeability and stability. However, none of the buffers completely fulfils all the criteria proposed by Good. Buffers are used under the assumption that they have no or very little interaction with metal ions present in environmental or biological studies. In the last decades, the increasing number of reports on buffer complexing properties with metal ions confirms otherwise. Results in similar experiments using different buffers have produced dissimilar results. ${ }^{\mathbf{1 2 - 1 4}}$

The aim of this work is to provide information for choosing an adequate buffer with full knowledge of their complexing properties, when it comes to systems with metal ions. Because the knowledge about the complexation between buffers and metal ions is necessary, this review summarizes the stability constants already reported and tries to predict possible complexation of metal-buffer systems that are still not described in the literature. Additionally, studies where biological effects induced by buffers were described are also critically reviewed and discussed.

\section{Families of Good's buffers and metal-buffer interactions}

The buffers proposed by Good et al. ${ }^{\mathbf{1 0}}$ in his first paper were: MES, ADA, PIPES, ACES, cholamine, BES, TES, HEPES, $\mathrm{N}$-(2acetamido)glycine, tricine, glycinamide hydrochloride and bicine.

Two more published documents from Good and coworkers $^{6,11}$ proposed eight additional buffers: MOPSO, MOPS, DIPSO, TAPSO, POPSO, HEPPSO, EPPS and TAPS, which raised the number of Good's buffers to twenty. Over the years, some more buffers have been suggested for biological application. More recently, Thiel et al. developed new buffers with butane containing side chains: MOBS, TABS, HEPBS and CABS, extending the useful buffering $\mathrm{pH}$ range into the more alkaline range. ${ }^{15}$

Nowadays, the Sigma catalogue ${ }^{\mathbf{1 6}}$ dedicates to them a special section, which is constituted by more than thirty biological buffers. Other companies also supply these buffers, such as Fischer Scientific ${ }^{\mathbf{1 7}}$ and VWR. ${ }^{\mathbf{1 8}}$ The buffers are listed in Fig. 1, where their $\mathrm{pH}$ buffering range is posted. The $\mathrm{pH}$ buffering range is based on the protonation constant(s) defined by:

$$
x \mathrm{H}^{+}+\mathrm{L}^{n-} \rightleftharpoons \mathrm{H}_{x} \mathrm{~L}^{(n-x)-}
$$

with

$$
K_{\mathrm{a}}=\frac{\left[\mathrm{H}_{x} \mathrm{~L}^{(n-x)-}\right]}{\left[\mathrm{H}^{+}\right]^{x}\left[\mathrm{~L}^{n-}\right]},
$$

where $\mathrm{L}$ stands for the buffer and $\mathrm{H}_{x} \mathrm{~L}$ stands for the protonated buffer. The formation constants for metal complexes are defined by:

$$
p \mathrm{M}^{n+}+q \mathrm{~L}^{m-}+r o H^{-} \rightleftharpoons \mathrm{M}_{p} \mathrm{~L}_{q}(\mathrm{OH})_{r}^{(p \cdot n-q \cdot m-r)}
$$

with

$$
\beta_{p q r}=\frac{\left[\mathrm{M}_{p} \mathrm{~L}_{q}(\mathrm{OH})_{r}{ }^{(p \cdot n-q \cdot m-r)}\right]}{\left[\mathrm{M}^{n+}\right]^{p}\left[\mathrm{~L}^{m-}\right]^{q}\left[\mathrm{OH}^{-}\right]^{r}}
$$

where $\mathrm{L}$ retains the same meaning as above and $\mathrm{M}_{p} \mathrm{~L}_{q}(\mathrm{OH})_{r}$ stands for metal complexes with a buffer. In the case of the formation of complexes involving the protonated form of a ligand, e.g. $\mathrm{MLH}$, the $\mathrm{OH}^{-}$should be replaced by $\mathrm{H}^{+}$.

\subsection{Morpholinic family}

MES, MOPSO, MOPS and MOBS are $N$-substituted aminosulfonic acids with a morpholinic ring (Table 1).

There is no evidence of complex formation for MES, MOPSO and MOPS with the main metals present in environmental and biological studies. MES, MOPSO and MOPS have shown no significant complexation with $\mathrm{Cd}$ and $\mathrm{Pb} .{ }^{19}$ Soares et al. ${ }^{19,20}$ showed that these three compounds also do not complex with $\mathrm{Cu}$ nor $\mathrm{Zn}$. Mash et al. ${ }^{21}$ concluded that no binding occurred between $\mathrm{Cu}$ and MES or MOPS. Accordingly, Renganathan and $\mathrm{Bose}^{7}$ did not find differences in the $\mathrm{Cu}$ inhibition of photosystem II electron transport in the presence of MES, concluding 


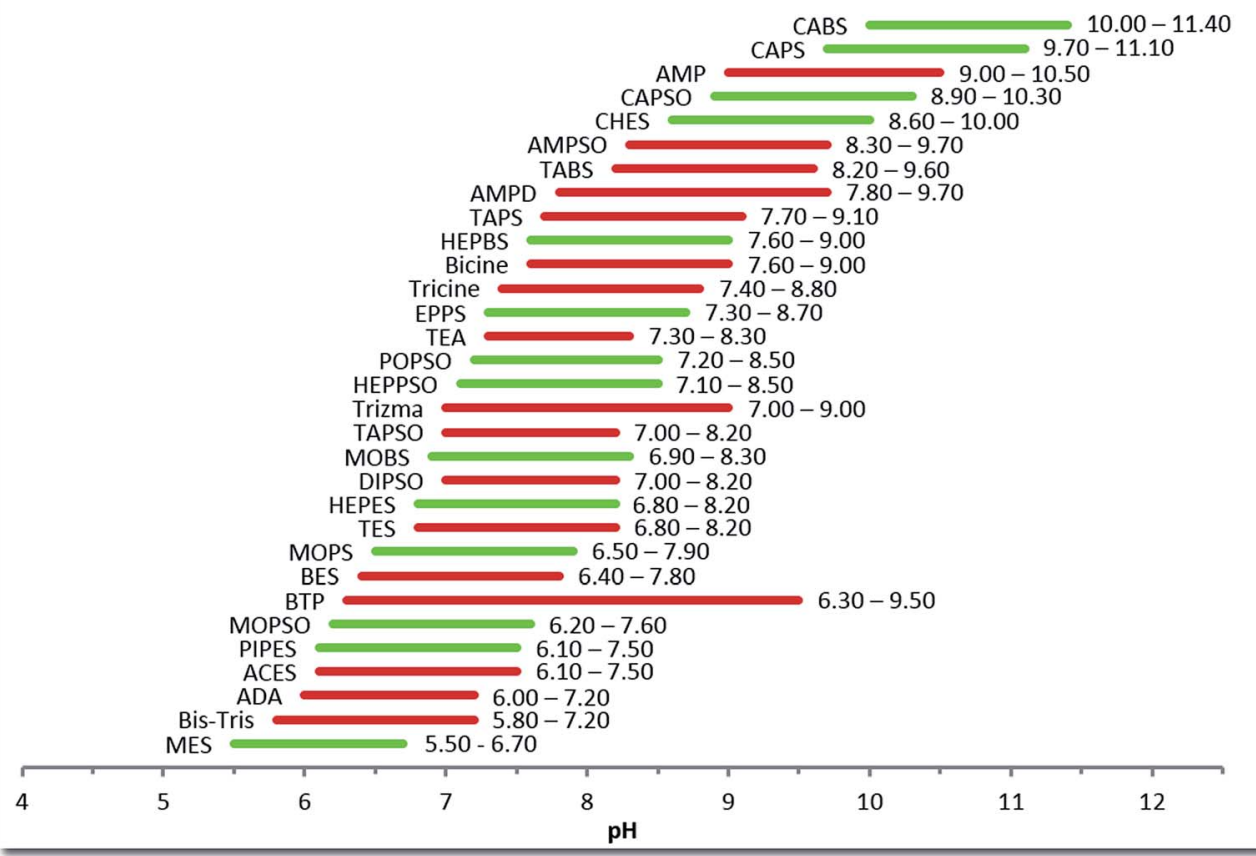

Fig. 1 List of buffers analyzed in this work and their pH range. Red - not suitable for general use; green - suitable for general use.

Table 1 Families of buffers and their respective structures

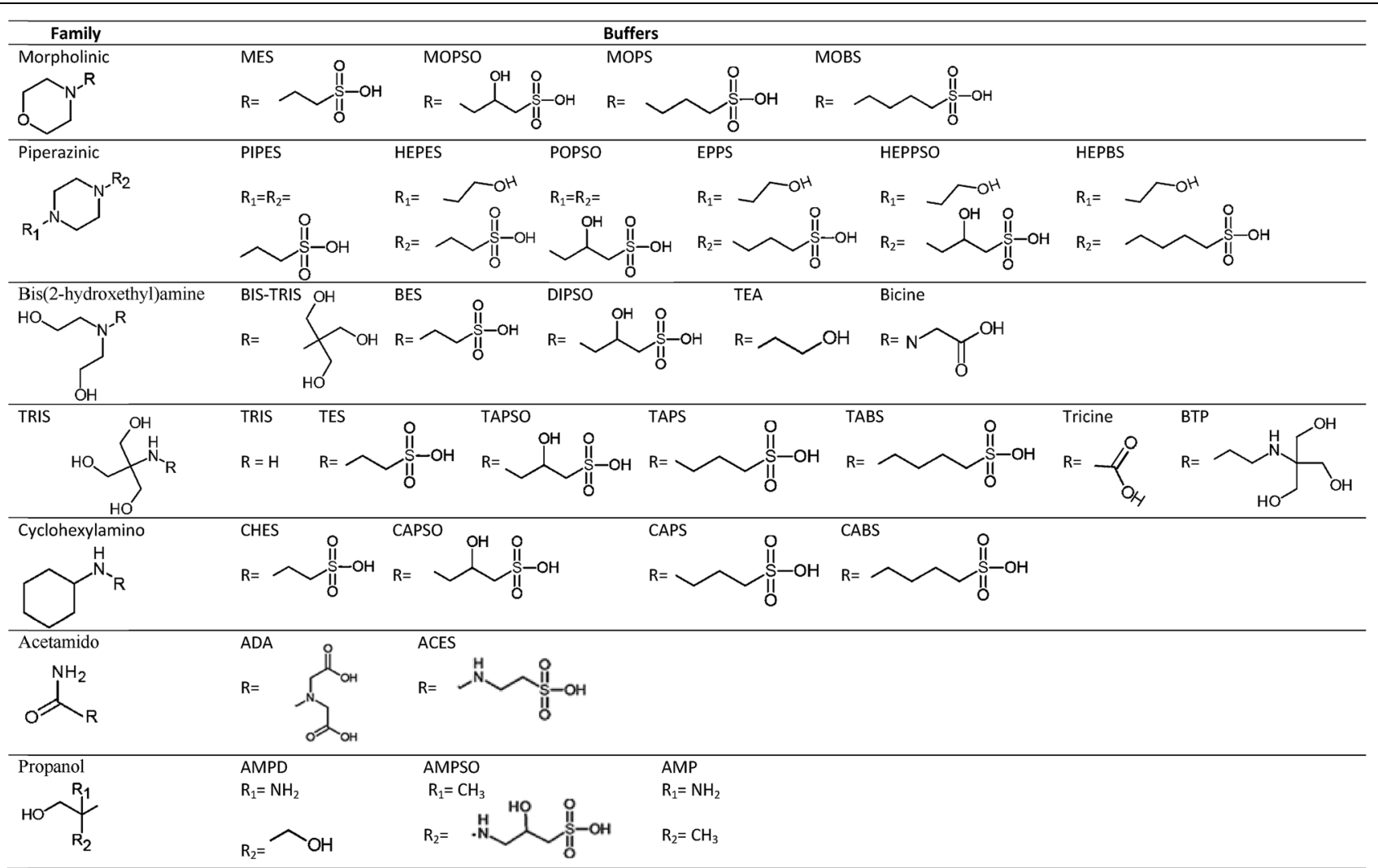


that no complexation occured. However, conflicting studies can be found. Anwar and $\mathrm{Azab}^{22}$ presented metal-buffer stability constants for MOPSO $(\mathrm{Cu}, \mathrm{Ni})$ and MOPS $(\mathrm{Cu}, \mathrm{Ni}, \mathrm{Mn}, \mathrm{Zn}, \mathrm{Co})$. The same research group ${ }^{23}$ considered the complexation of MES with $\mathrm{Cu}, \mathrm{Ni}, \mathrm{Co}, \mathrm{Zn}, \mathrm{Ca}, \mathrm{Mg}$ and $\mathrm{Mn}$ and proposed stability constants for the formation of these complexes. Wyrzykowski et al. ${ }^{24}$ agrees with the formation of MES complexes with $\mathrm{Ni}$ and Co, with ML constants significantly lower than the ones determined by Azab and Anwar; ${ }^{23}$ however, $\mathrm{ML}(\mathrm{OH})_{2}$ complexes were also included in the model, which can explain such differences. Complexes of Fe(III) and Cr(III) with MES, MOPSO, MOPS and MOBS were studied by Gupta et al. ${ }^{25}$ and Taha et al. ${ }^{26}$ who admitted that when these buffers are used in media where metal exists, interferences may occur due to metal complex formation. In the studies conducted by Johnston and Singer, ${ }^{27}$ the results indicate that no complexation occurs between MES and Fe(II).

Despite these reports of complexation, most of the authors agree that there is no evidence of significant bonding to metals and several studies specifically chose MES or MOPSO due to their inability to interfere with the most important metals in biological and environmental applications. ${ }^{28-30}$ In fact, for MES, the analytical techniques used by Soares et al..$^{19,20}$ and by Mash et al. ${ }^{21}$ are more sensitive than those used by Azab. ${ }^{23}$ Additionally, the software used for the refinement of the potentiometric data collected by Azab did not contain graphical analysis. In this case, the refinement of the complexation models is guided only by statistical parameters, which may lead to false-positives. Furthermore, the data from Renganathan and Bose $\mathrm{B}^{7}$ and Johnston and Singer $^{27}$ support the idea that MES is a noncomplexing buffer. For both MOPSO and MOPS, the same conclusions can be drawn, which means that these compounds are capable of buffering solutions within $\mathrm{pH} 6.20$ to 7.60 and 6.50 to 7.90 (Fig. 1), respectively, without any or significant interaction with metal ions in solution. Given its structural similarity with MES and MOPS, a similar behaviour is expected for MOBS which has buffer capabilities between pH 6.90 to 8.30.

\subsection{Piperazinic family}

PIPES, HEPES, POPSO, EPPS, HEPPSO and HEPBS contain a piperazinic ring (Table 1). Like MES and MOPS, PIPES and HEPES are frequently used in environmental, analytical and biological studies due to their lack of ability to complex with metal ions. There are evidences that PIPES and HEPES do not complex with $\mathrm{Cu}^{31,32}$ and slightly complex with $\mathrm{Pb}^{33}$ Renganathan and $\mathrm{Bose}^{7}$ also concluded about the negligible bonding between $\mathrm{Cu}$ and HEPES and Hoffman et al. ${ }^{34}$ obtained a similar result about $\mathrm{Cd}$ and PIPES. However, stability constants for PIPES complexes with $\mathrm{Cu}$, Ni, Co and $\mathrm{Zn}^{24,35}$ and HEPES complexes with $\mathrm{Cu}, \mathrm{Zn}, \mathrm{Pb}$ and $\mathrm{Cd}^{36,37}$ have been described in the literature. $\mathrm{Yu}$ et $a l .^{38}$ also demonstrated formation of $\mathrm{Cu}(\mathrm{II})-$ HEPES complexes while PIPES shows no evidence of bonding with $\mathrm{Cu}$. It is worth noting that the constants for $\mathrm{Ni}$ and $\mathrm{Co}$ are very similar, in disagreement with the general trend where $\mathrm{Ni}$ (II) presents larger stability constants than $\mathrm{Co}$ (II). Also, most work made use of potentiometric data for the refinement of data. As it was discussed above, the application of this technique for complexation studies with these types of compounds leads to some doubt about these constants, even more when other, more sensitive techniques, were applied to some of these and other cases and no complexation was detected. Therefore, PIPES and HEPES are, together with MES and MOPSO, more adequate to substitute Tris and phosphate than other zwitterionic buffers. ${ }^{39}$

While Azab et al.$^{64}$ shows that HEPPSO complexes with metal ions, the work performed by Soares and Conde, ${ }^{33}$ Anwar $^{37}$ and Mash et $a l^{21}$ demonstrated that no complexation occurs for HEPPSO, except that Mash was able to determine a stability constant for the HEPPSO-Cu(II) system. The additional hydroxyl group in HEPPSO may be responsible for this slightly different behaviour. Therefore, in the case of HEPPSO with $\mathrm{Cu}$, special attention is needed if one wants to use it to buffer $\mathrm{Cu}(\mathrm{II})$ solutions. Apart from this case, this buffer is suitable for use with other metals in solution.

EPPS (Table 1) is described to complex weakly with $\mathrm{Cu}$ and $\mathrm{Pb}$ and does not form complexes with $\mathrm{Zn}$ and $\mathrm{Cd} .{ }^{40}$ However, considering the structural similarities between EPPS and HEPES, it seems that EPPS is possibly a good buffer to be used in media with metal ions. There are not many studies about complexation of POPSO; however, it was described that it binds with $\mathrm{Cu}^{32}$ No other complexation works studying the interaction between this buffer and other metal ions were found in the literature.

For HEPBS (Table 1), no complexing properties are described in the literature. An analysis of its structure reveals that it is very similar to that of HEPES and EPPS; therefore, the same chemical behaviour is expected. Thus, HEPBS is an appropriate buffer to be used in media with metal ions.

\subsection{Bis(2-hydroxyethyl)amine family}

The bis(2-hydroxyethyl)amine family includes bis-Tris, BES, DIPSO, TEA and bicine (Table 1). For bis-Tris, DIPSO and TEA, there are stability constants described in the literature for most of the metals included in environmental and biological studies. ${ }^{8,41-45}$ In the case of BES, the only evidence of complexation found in the literature corresponds to $\mathrm{Cu}$ and $\mathrm{Co}^{8,46}$ Bicine also complexes with most of the metals studied. ${ }^{8,47}$ Based on their complexation properties, the use of buffers from this family is not advisable in environmental and biological studies containing metals, unless stability constants are taken into consideration (see below, Section 3.1.7.1.).

\subsection{Tris family}

Tris, TES, TAPSO, TAPS, TABS, tricine and BTP belong to the Tris group (Table 1). TES, TAPSO and tricine have stability constants described for most of the metals. $8,23,25,26,43,48-54$ Renganathan et al. ${ }^{7}$ found interferences in $\mathrm{Cu}$ inhibition of photosystem II electron transport due to bonding between $\mathrm{Cu}$ and TES, Tris and tricine. For TAPSO and TAPS, there is evidence of complexation with $\mathrm{Cd}, \mathrm{Co}, \mathrm{Cu}, \mathrm{Pb}, \mathrm{Ni}$ and $\mathrm{Zn}{ }^{41,43,49-51,55,56}$ Muzikar et al. ${ }^{57}$ warned against the use of TAPS in buffering electrolytes and presented stability constants with $\mathrm{Ca}, \mathrm{Mg}, \mathrm{Sr}$ and $\mathrm{Ba}$, but the values are extremely low. In the case of TABS, only values for $\mathrm{Fe}$ and $\mathrm{Cr}$ were found in the 
literature, ${ }^{25,26}$ but due to its structure (Table 1), it probably complexes with other metals. Fisher et al. studied the complexation properties of Tris with a large array of divalent metal ions. ${ }^{58}$

BTP is the only buffer mentioned in this paper that has two well defined protonation constants due to the presence of two secondary amines. It is a strong complexing agent as was shown in studies with $\mathrm{Cd}, \mathrm{Co}, \mathrm{Cu}, \mathrm{Ni}, \mathrm{Pb}$ and $\mathrm{Zn} .^{46,53,54}$

\subsection{Cyclohexylamino family}

The cyclohexylamino family comprises CHES, CAPSO, CAPS and CABS (Table 1). Published complexation studies have only been described for CHES. ${ }^{23}$ Data about the complexation of the other three compounds was not found in the literature. A previous work of our team demonstrates that CAPSO, CHES and CAPS display weak complexation capabilities with $\mathrm{Cu}, \mathrm{Pb}, \mathrm{Cd}$ and $\mathrm{Zn}$. CAPSO, with its hydroxyl moiety, presents the higher complexation capability. Their buffering capacity ranges between $\mathrm{pH}$ 8.60 and 11.40 (Fig. 1), which usually excludes them as the first choice in biological and environmental studies, unless higher $\mathrm{pH}$ is desired.

\subsection{Acetamido family}

ADA and ACES, both belonging to the acetamido family (Table 1), form complexes with most of the common metals in studies. ${ }^{\mathbf{8 5 9}}$ In fact, ADA has been used as a complexing agent to remove metals from contaminated soils, namely $\mathrm{Pb}$ and $\mathrm{Cd},{ }^{60,61}$ proving its inadequacy to be used as a buffer in the presence of metals without taking into account the stability constants.

\subsection{Propanol family}

This family comprises AMPD, AMPSO and AMP buffers (Table 1). Data is found related to complexation between AMP and $\mathrm{Cu}$, $\mathrm{Cd}$ and $\mathrm{Ni}^{8}$ On the other hand, there are no published studies concerning the complexation of AMPD. However, a previous work of our team (data not published) demonstrates that AMPD has some complexation capabilities with $\mathrm{Pb}, \mathrm{Cd}$ and $\mathrm{Zn}$. Studies about AMPSO complexation have shown that this buffer has the ability to bind with $\mathrm{Ca}, \mathrm{Co}, \mathrm{Cu}, \mathrm{Pb}, \mathrm{Mg}, \mathrm{Mn}$ and $\mathrm{Ni}^{42,43,62-65}$

\subsection{Complexation studies between Good's buffers and lanthanides and others ions}

Complexation studies between buffers and other metal ions that are not so common have been performed and are useful when dealing with these specific elements and species. Azab et $a l .{ }^{66}$ and Orabi et $a l .{ }^{67}$ determined the stability constants of the formation of the complexes between lanthanides and several Good's buffers. The complexation of Tris with La, Ce and Th was studied by El-Roudi and co-workers. ${ }^{68}$ El-Gahami et $a l^{69,70}$ studied the complexation of MES and MOPSO with dibutyltin(Iv) and dimethyltin(Iv) cations.

\section{Employment of Good's buffers in biochemical, biological and environmental studies}

Good's buffers have been used in many biological studies since the time they were first described ${ }^{\mathbf{1 0}}$ and chemical suppliers made them easily available for use in the laboratory. Table 2 presents examples of the applications of Good's buffers, such as in biomolecular, biochemical, molecular and cellular biology, toxicology and environment studies, where a wide array of techniques, such as chromatography, ${ }^{71-74}$ electrophoresis, ${ }^{75-78}$ spectrophotometry $^{79-81}$ and X-ray crystallography ${ }^{\mathbf{8 1 , 8 2}}$ were used.

Good's buffers seem to be adequate for toxicity studies. It was shown that MES buffer is not toxic to the yeast $S$. cerevisiae. ${ }^{83}$ No toxic effects of DIPSO and HEPES on the alga Amphidinium carterae were observed. ${ }^{84}$ In a similar way, no toxicity for small crustaceans (commonly called water fleas) Daphnia magna and Daphnia pulex was reported when HEPPSO and HEPES were used as buffers. ${ }^{85}$

\subsection{Are Good's buffers so good?}

When choosing a buffering agent, among other requirements (such as its solubility and ionic strength), the $\mathrm{p} K_{\mathrm{a}}$ value of the buffer, which should be close to the $\mathrm{pH}$ in which the biological study will be carried out, should be taken into account, together with the compatibility of the buffer with the reaction system, namely the impact on cell structures and macromolecules, complexing and redox characteristics.

Although there is no perfect buffer, i.e., one that displays all the characteristics enumerated by Good (Section 1), the zwitterionic $N$-substituted aminosulfonic acids seem to meet most of them. However, it should be emphasized the importance of the knowledge of the potentialities and limitations of the different buffers, which must be taken into account in the moment of the buffer selection. In other words, particular care should be taken when selecting the buffer for a given experiment, since the buffer may interact with the different components of the system under study. In many cases, for instance in enzymatic studies, buffers are usually present at higher concentration than the other components in reaction mixtures. ${ }^{5}$ Thus, any kind of buffer interaction can deeply affect the results.

3.1.1. Impact of buffers on cell growth and survival. Different buffers can be added to the culture medium in order to control the $\mathrm{pH}$. MES is not metabolized by bacteria and eukaryotic cells; therefore, it is often used to prepare buffered culture media. Although MES can be toxic at high concentration $\left(>10 \mathrm{mmol} \mathrm{l}^{-1}\right),{ }^{86}$ this buffer has been also used in culture media for plant cells. ${ }^{87}$ ACES, MOPS and MOPSO were employed as a buffer component of charcoal yeast extract medium for the optimal growth of Legionella pneumophila, without causing the growth inhibition observed with some inorganic buffers. ${ }^{88}$ MES, MOPS and bis-PIPES seem to be appropriate buffers for mammalian cell culture. ${ }^{2}$ It was also described that chilled bovine embryos, stored for 7 days in a medium supplemented 
Table 2 Examples of biological uses of Good's buffers

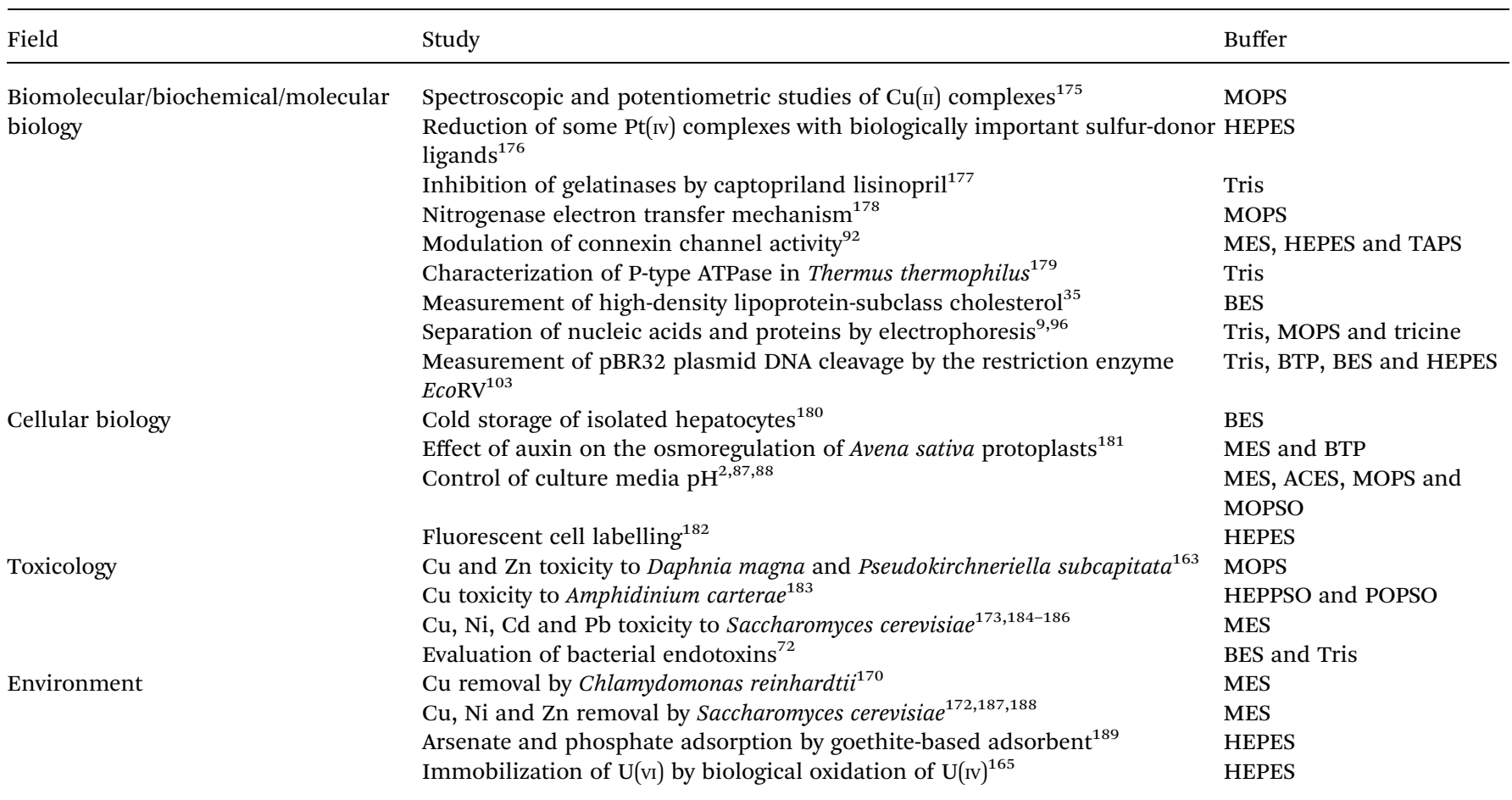

with HEPES, had much higher survival than embryos stored in the same medium with TES, PIPES, MOPS or EPPS. ${ }^{89}$

3.1.2. Interaction of buffers with cell membranes. MES, MOPS and HEPES can modify lipid interactions. ${ }^{3}$ HEPES affects membrane potentials in neuronal cells, ${ }^{90}$ MOPS can influence the thickness and barrier properties of rat endothelial surface layers $^{91}$ and MES, HEPES and TAPS, when in the protonated form, inhibit the connexin channel activity in rat liver cells. ${ }^{92}$ Animal cells seem to be more sensitive to the presence of the buffer, most likely due the absence of a cell wall. In fact, a study using as a cell model the yeast Saccharomyces cerevisiae revealed the maintenance of the membrane integrity when the cells were incubated in $10 \mathrm{mM}$ MES at $\mathrm{pH} 6.0 .^{83}$

3.1.3. Interaction of buffers with macromolecules. Buffers are used in most in vitro reaction systems in order to keep constant the $\mathrm{pH}$ of the solution. Different works described the interaction of the buffer with macromolecules such as proteins and nucleic acids.

MES, MOPS and MOPSO interact with the peptide backbone of bovine serum albumin, leading to a net stabilization of the protein. ${ }^{93}$ In a study using as a model the naturally aggregating Escherichia coli protein (RecA) (which among other functions, performs DNA repair), it was found that the buffers (HEPES, MES and Tris) had minimal effect on nucleotide binding. ${ }^{94}$ However, the interaction of the buffers with the protein had significant effects on their thermal stability, unfolding transitions and the dsDNA nucleation of RecA. ${ }^{94}$ It was also described that the activity of the enzyme endo- $\alpha$-D-mannosidase was affected by the buffer used. The higher activity was described when MES and MOPSO were used at $\mathrm{pH}$ 7.0; the enzyme activity was strongly reduced in HEPES or HEPPS buffer and was essentially eliminated in Tris buffer. ${ }^{95}$ The inhibitory enzyme effect of Tris was also described in the case of microperoxidase11 (MP-11).

Buffers are an integral part of the electrophoresis technique, commonly used for the separation of nucleic acids and proteins, since it requires a constant and precise $\mathrm{pH}$ value. Trisbased buffers, such as Tris-acetate EDTA (TAE: $40 \mathrm{mmol} \mathrm{l}^{-1}$ Tris-acetate; $1 \mathrm{mmol} \mathrm{l}^{-1}$ EDTA; $\mathrm{pH}$ 8.3) and Tris-borate-EDTA (TBE: $90 \mathrm{mmol} \mathrm{l}^{-1}$ Tris; $90 \mathrm{mmol} \mathrm{l}^{-1}$ boric acid, $2 \mathrm{mmol} \mathrm{l}^{-1}$ EDTA; pH 8.3) are generally used in the electrophoretic separation of DNA, using agarose gel. ${ }^{9}$ In the case of electrophoretic RNA separation, agarose gels containing denaturing agents, such as formaldehyde or glyoxal, have been used. Denaturing agents decompose during electrophoresis, altering the $\mathrm{pH}$ of the gel. In addition, RNA is unstable in slightly alkaline solutions. Due to these reasons, MOPS buffer $\left(\mathrm{p} K_{\mathrm{a}} 7.2\right)$ has been used for denaturing gel electrophoresis of RNA. ${ }^{9}$ The separation of proteins is usually carried out using sodium dodecyl sulphate (SDS) polyacrylamide gel electrophoresis (SDS-PAGE). For this purpose, Tris-glycine $\left(25 \mathrm{mmol} \mathrm{l}^{-1}\right.$ Tris; $250 \mathrm{mmol} \mathrm{l}^{-1}$ glycine; pH 8.3) or Tris-tricine $\left(100 \mathrm{mmol} \mathrm{l}^{-1}\right.$ Tris; $100 \mathrm{mmol} \mathrm{l}^{-1}$ tricine; pH 8.2) are common buffers in SDS-PAGE. ${ }^{\mathbf{9}}$

Buffer properties also affect protein, lipid and nucleic acid extraction. For example, Davies and Goldberg ${ }^{97}$ have introduced HEPES in the extraction buffer to prevent the damage of proteins in red blood cells. HEPES was also employed with glutamic acid in a fixation method, which results in great preservation of proteomic and nucleic content ${ }^{98}$ as well as in the extraction of nucleic material. ${ }^{99}$ Fowler et al. ${ }^{100}$ have shown that Tris buffer inhibits monoamine oxidase (MAO) activity in a noncompetitive manner; the authors warn against its use in MAO 
extraction and estimation of activity. The concentration and $\mathrm{pH}$ of the buffer also play a role in the extraction protocols. It was described that $150 \mathrm{mmol}^{-1}$ tricine buffer at $\mathrm{pH} 8.0$ allowed the separation of metallothioneins by capillary zone electrophoresis. ${ }^{\mathbf{1 0 1}}$

Neutral pH amine-based buffers, such as MOPS, HEPES, BES, TES and tricine, interact and form complexes with DNA. ${ }^{102}$ It was found that the interaction of the buffer with the DNA affected the kinetic and binding parameters of cleavage of the plasmid pBR322 by the restriction endonuclease EcoRV. The authors found decreasing reaction rates from HEPES, TES to Tris. It was proposed that the modification of the binding of the enzyme to DNA was associated with the availability of protonated amines of the buffer to act as counter ions to the DNA phosphate. $^{\mathbf{1 0 3}}$

Zwitterionic buffers influence mRNA expression of in vitro produced bovine embryos. It was shown that transcription levels and embryo development were more profoundly affected by the use of TES than by HEPES and were least affected by MOPS. ${ }^{104}$

3.1.4. Influence on DNA, RNA and protein measurement. Buffers should not absorb at wavelengths longer than $230 \mathrm{~nm}$, since many spectrophotometric determinations of DNA, RNA and proteins are performed in this range of wavelengths. However, it is known that ACES displays a significant absorption at $230 \mathrm{~nm}$ and ADA an absorption in UV range below 260 nm. ${ }^{10}$

It is reported that Tris interferes with the Bradford protein assay. HEPES, PIPES, EPPS, bicine and MOPS interfere with Lowry protein determination; however, HEPES and MOPS do not interfere with Bradford or bicinchoninic acid assays. ${ }^{4,96,105,106}$

3.1.5. Impact of buffers in redox studies. MES does not form radical species. On the other hand, radical species can be formed from HEPES, PIPES and EPPS, ${ }^{4}$ which means that these buffers are not suitable for redox studies. It was also described that MOPS, MES, PIPES, HEPES and EPPS can be oxidized by $\mathrm{H}_{2} \mathrm{O}_{2}$; nevertheless, since buffer oxidation is slow, no significant impact on biological/biochemical systems is expected to occur. ${ }^{107}$ MES, MOPS, HEPES and Tris retarded Fe(II) autoxidation kinetics in the presence or absence of ferritin. ${ }^{108}$ In addition, it was described that MES, PIPES and HEPES interfere with phenolic oxidation by peroxidases. ${ }^{109}$ Formation of tricine-NO radicals was described in the presence of peroxide-forming enzymes; ${ }^{110}$ therefore, care should be taken with the use of tricine if proteins with oxidase activity are present.

3.1.6. Effects of buffer in chromatographic separations. Some authors point out the relevance of the careful selection of the buffer used in chromatographic protocols, due to its possible interaction. Heinisch and Rocca ${ }^{\mathbf{1 1 1}}$ studied the effects of several factors, including buffer types, such as Tris and BTP, at $30 \mathrm{mmol} \mathrm{l}^{-1}$, on the retention of ionizable compounds in reversed-phase liquid chromatography. The authors showed that the type of the buffer could affect the performance of the separation. Borges and Collins ${ }^{112}$ described that buffers, such as tricine ( $\mathrm{pH}$ 8.0, $20 \mathrm{mmol} \mathrm{l}^{-1}$ ), affect the high-performance liquid chromatography (HPLC) stability and performance of stationary phases [immobilized poly(methyloctylsiloxane) on silica-PMOS-SiO ${ }_{2}$ ]. It was also shown that high $\mathrm{pH}$ values of the mobile phase reduce the ion-exchange interactions between the basic solutes and the stationary phase, resulting in lower retention factors. Despite $\mathrm{PMOS}-\mathrm{SiO}_{2}$ stationary phases displaying low stability in alkaline mobile phases, the use of buffers, such as tricine or Tris, gives unique selectivity properties to the mobile phase, making them promising for pharmaceutical analyses. ${ }^{\mathbf{1 1 2}}$ Comparative to inorganic buffers, buffers such as MES and Tris are adequate for capillary electrochromatography (CEC) due to their low ionic mobility. ${ }^{113}$ Jiskra et al. ${ }^{114}$ studied the influence of twelve commonly used organic and inorganic buffers on the chromatographic behaviour of HPLC and CEC. The authors found that inorganic buffers had greater impact on the chromatographic behaviour compared to organic buffers; within organic buffers, MES $\left(1 \mathrm{mmol} \mathrm{l}^{-1}, \mathrm{pH}\right.$ 6.0) and Tris (0.5-10 $\mathrm{mmol} \mathrm{l}^{-1}, \mathrm{pH}$ 8.0) presented exceptional behaviour.

3.1.7. Influence of buffer complexation characteristics on experimental results. There are a number of works in which, although no initial consideration was given to the possible interference of the buffer, the authors concluded that part of their results may be conditioned by the metal-buffer pair used. Wang et al. ${ }^{115}$ recognized that several components in their chromatographic system may be competing for metal binding with bis-Tris. Minami et al. ${ }^{116}$ found substantial differences when different buffers, such as ADA and TAPS, were used for the identification of metallothionein isoforms, using capillary zone electrophoresis. BES and Tris were found to affect the results of bacterial endotoxin tests in the presence of different metal ions. ${ }^{72}$ In the study of photosystem II inhibition by $\mathrm{Cu}$ (II), it was concluded that Tris, tricine and TES complexed with $\mathrm{Cu}$ (II), with substantial effects on the final results. ${ }^{7}$ The choice of buffer also influenced the determination of the thermodynamic parameters associated with the interaction of alkaline metal ions with citric acid. ${ }^{117}$ On the other hand, AMPSO and TAPSO have been described to inhibit the activity of catalysts in chemical reaction due to their capacity to bind with $\mathrm{Cu}(\mathrm{II})$, which was not a problem when HEPES was used as a buffer. ${ }^{14}$ Nakano et al., while examining MOPSO, ACES, BES, MOPS, TES, HEPES and 3,3-dimethylglutaric acid (DGA) in an attempt to find the optimal conditions for the determination of $\mathrm{Mn}$ (II) by flowinjection photometry, ultimately selected DGA, as it was the only one to present no effects on the peaks obtained up to a concentration of $1 \times 10^{-2} \mathrm{M} \cdot{ }^{118} \mathrm{BTP}$ is recognized as a strong coordinating buffer to $\mathrm{Cu}(\mathrm{II})^{46}$ and should be avoided in the use of an assay for proteases, which uses a water soluble fluorescein-based ligand-Cu based method. ${ }^{119}$ In the study of the interaction between succinate dehydrogenase and ubiquinone-binding protein from succinate-ubiquinone reductase, a decrease in protein activity was recorded as a consequence of the buffer (HEPES, TES, and TAPS) influence. ${ }^{120}$ Iron autoxidation rates are affected by the presence of buffers (Tris, MES, MOPS and HEPES), which ultimately alter the measured ferroxidase activity from horse spleen. ${ }^{108}$ In assessing the possible effects of buffers on a size exclusion chromatographic protocol's mobile phase for the quantification of $\mathrm{Cu}, \mathrm{Fe}$ 
and Zn-containing metalloproteins, Tris, HEPES and MOPS showed different results from those obtained with phosphate buffered saline (PBS) solution for $\mathrm{Fe}$ and Zn-containing proteins. $^{121}$

3.1.7.1. The knowledge of the complexing characteristics of the buffer. In many studies, experiments were conducted with metal ions in a buffered medium, where buffers known as being metal complexing ligands, as described in the previous section, were used. Some authors have taken into account this information and, accordingly, the free metal ion concentrations have been calculated. In order to study metal coordination to $\mathrm{Zn}$ (II) binding sites, Magyar and Godwin ${ }^{\mathbf{1 2 2}}$ used software for simulating the speciation of metals with buffers, such as bis-Tris. A similar approach was undertaken by Amar et al. ${ }^{\mathbf{1 2 3}}$ and Fayyazuddin et al., ${ }^{\mathbf{1 2 4}}$ who also performed simulations for $\mathrm{Zn}$ (II) and the buffers used, like ADA, using known stability constants. Sensi et al. ${ }^{\mathbf{1 2 5}}$ also performed simulation calculations for MOPS, despite this no simulations have been performed for ADA with the metal in the system. Jenkins et al. ${ }^{\mathbf{1 2 6}}$ took into consideration buffer complexation and made appropriate calculations regarding the TES-ATP-metal systems in their study. In the studies of inhibition of glycine receptors by $\mathrm{Zn(II),} \mathrm{Thio} \mathrm{et} \mathrm{al.}{ }^{127}$ used tricine to chelate and control $\mathrm{Zn}$ and then calculated the free metal ion in solution. Stelzer et al. ${ }^{\mathbf{1 2 8}}$ used computer programs to calculate free metal ion concentration where BES and $\mathrm{Ca}$ (II) were present in solution. Other researchers replaced buffers, as they were aware of possible complexation. For example, Atkinson et al. ${ }^{129}$ skipped the use of AMPD with Zn as it would complex.

3.1.7.2. Absence of information related to complexing properties. The major part of the studies found in the literature do not indicate if complexation between metal ions and the buffer(s) used has been taken into account. Reasons for that can be that the authors skipped its writing, neglected it or were unaware of the possible complexation effects that buffers might have. For instance, Bayen et al. ${ }^{\mathbf{1 3 0}}$ studied Cd speciation and bioavailability in the presence of several buffers (MES, MOPS, TAPS, AMPSO, HEPES and ACES) to test the pH effect. In this work, buffers were used as "non-complexing" agents although stability constants for complexes between Cd and TAPS, AMPSO and ACES are described in the literature.

There is also the case where no complex stability constants are available in the literature and therefore, no complexation could be predicted. These situations usually involve metal ions not commonly studied in speciation works or metals, such as $\mathrm{Ca}(\mathrm{II})$ or $\mathrm{Mg}$ (II). For example, Ono et al. ${ }^{\mathbf{1 3 1}}$ studied the variation of photosynthetic oxygen evolution when $\mathrm{Ca}$ (II) was replaced by $\mathrm{K}(\mathrm{I}), \mathrm{Rb}(\mathrm{I})$ and $\mathrm{Cs}(\mathrm{I})$, in the presence of bis-Tris and MES. In turn, Wheatley et al. ${ }^{132}$ used bis-Tris and TES in the crystallization and kinetics of $\beta$-galactosidase, an enzyme with $\mathrm{Mg}$ (II) and $\mathrm{Na}(\mathrm{I})$ active centres, respectively, while Beeler et al. ${ }^{\mathbf{1 3 3}}$ studied rat skeletal $\mathrm{Mg}$ (II)-ATPase in the presence of ADA. In these and other similar situations, buffer complexation is unknown. If it occurs, no impact on the studies performed was considered.

3.1.7.3. Presence of other ligands in solution. In several studies, some of the components present in the medium under study have themselves high complexing capabilities and buffer interference is thought to be simply nonexistent. These studies involve proteins with heme groups, ${ }^{134-136} \mathrm{Zn}$-finger motifs, ${ }^{137-139}$ metalloproteins ${ }^{\mathbf{1 1 6 , 1 3 3 , 1 4 0 - 1 4 2}}$ and/or other complexing agents in solution. ${ }^{\mathbf{8 1 , 1 4 3 - 1 4 5}}$ In fact, the concentrations of the compounds used, and most importantly the ratio of the buffer concentration to the complexing compound concentration in the medium, are within values that support the idea that no interference of the buffer occurs.

In other studies, the concentrations of metal, buffer and/or component with complexing properties under study may raise doubts regarding the possible interference of buffers. Even if the affinity of the biological component to the metal is much larger than that of the buffer to the metal, a substantial difference in concentration may favour the formation of metal-buffer complexes due to a mass effect. There are some works that can be mentioned as examples of this situation. Juillard et al. ${ }^{\mathbf{1 4 6}}$ used about 1000 times more buffer (bis-Tris) than ferric heme and apomyoglobin in their binding studies, whilst Seto et al. ${ }^{147}$ used 40 times more buffer than luciferin and EDTA; in this study, a sensitive bioluminescent enzyme immunoassay based on luciferin, where $\mathrm{Mg}$ (II) plays a vital role, was used. For BTP buffer, which is a strongly complexing ligand, some more examples are found in the literature. For example, Ejnik et al. ${ }^{\mathbf{1 4 8}}$ used a BTP buffer concentration about 2500 times larger than the concentration of the apometallothionein domains. Additionally, in Kanaori's study related to the effect of $\mathrm{Cd}$ on the histidinol dehydrogenase metal binding, a BTP concentration several thousand times larger than that of histidinol was used. ${ }^{149}$ Other situations where the concentration of buffer used is substantially higher than that of existing components under study can be found in the literature related to other buffers such as TES, ${ }^{150}$ Tris, ${ }^{136}$ TEA, ${ }^{151,152}$ TAPS $^{153}$ and AMPSO. ${ }^{154}$ Even though we cannot definitively assert that buffer interferences exist in such studies, a cautious analysis of the results should be considered.

\subsection{HEPES, MES and other Good's buffers}

HEPES is a buffer widely used. It is a non to very weak complexing agent, as noted in the previous section. Thus, it is suitable for most studies with metal ions. In fact, it is widely used throughout all fields of research, such as biomolecular, ${ }^{138,139,155-157}$ biochemical, ${ }^{\mathbf{9 4 , 1 2 1 , 1 5 8 - 1 6 0}}$ toxicological, ${ }^{161-163}$ cellular $^{79,125,164,165}$ and environmental ${ }^{138,157,165,166}$ studies. However, attention should be paid to other possible interferences from HEPES, such as interferences in oxidation reactions, ${ }^{107,109,166}$ interferences with $\mathrm{DNA}^{\mathbf{1 0 2}}$ and other biological molecules. ${ }^{3,92,93,103}$

Another option is MES, which is also a non-complexing ligand and has been widely used. ${ }^{157,167-173}$ As it was previously discussed in Section 2, there are other possible buffers, such as MOPS or PIPES, or even MOPSO, HEPPSO, POPSO and EPPS. For each one, a careful research should be made in order to ensure that no effects occur in studies where these buffers are intended to be used. 


\section{Suitability of pH buffer use based on metal complexation}

Based on the analyses of the information described in the previous sections, the stability constants found in the literature, together with a comprehensive study of chemical speciation simulation for all relevant metal-buffer pairs, a table containing qualitative information of the complexation magnitude strength between the different buffers and metals was elaborated (Table 3). Metal chemical speciation calculations were performed using the computer program MINEQL+ Version $4.5,{ }^{174}$ which generates chemical equilibrium concentrations of all species being considered in the model by the program reactions (data not shown). In a general scenario, from the analysis of Table 3, we can say that fourteen buffers arise as best candidates (Fig. 1): MES, PIPES, MOPSO, MOPS, HEPES, MOBS, HEPPSO, POPSO, EPPS, HEPBS, CHES, CAPSO, CAPS and CABS.

As previously detailed, some studies describe complexation of MES with metal ions while others support that MES is a noncomplexing agent. However, based on the analytical techniques employed in those studies, in the data analyses and behaviour

Table 3 Overview of the complexation magnitude strength between the different metal-buffer pairs ${ }^{c}$

\begin{tabular}{|c|c|c|c|c|c|c|c|c|c|c|c|c|}
\hline \multirow{3}{*}{$\begin{array}{c}\text { Group } \\
\text { Type } \\
\text { Buffer }\end{array}$} & 2 & & 6 & 7 & 8 & 9 & 10 & 11 & & 2 & 14 & \\
\hline & \multicolumn{2}{|c|}{$\begin{array}{c}\text { Alkaline } \\
\text { earth metal }\end{array}$} & \multicolumn{10}{|c|}{ Transition metal } \\
\hline & $\mathrm{Mg}(\mathrm{II})$ & $\mathrm{Ca}(\mathrm{II})$ & $\mathrm{Cr}$ (III) & $\mathrm{Mn}$ (II) & $\mathrm{Fe}(\mathrm{III})$ & $\mathrm{Co}$ (II) & $\mathrm{Ni}(\mathrm{II})$ & $\mathrm{Cu}(\mathrm{II})$ & $\mathrm{Zn}(\mathrm{II})$ & $\mathrm{Cd}(\mathrm{II})$ & $\mathrm{Pb}(\mathrm{II})$ & Final $^{a}$ \\
\hline MES & & & & & & & & & & & & $(+)$ \\
\hline Bis-Tris & & & & & & & & & & & & $(-)$ \\
\hline ADA & & & & & & & & & & & & $(-)$ \\
\hline ACES & & & & & & & & & & & & $(-)$ \\
\hline PIPES & & & & & & & & & & & & $(+)$ \\
\hline MOPSO & & & & & & & & & & & & $(+)$ \\
\hline BTP & & & & & & & & & & & & $(-)$ \\
\hline BES & & & & & & & & & & & & $(-)$ \\
\hline MOPS & & & & & & & & & & & & $(+)$ \\
\hline TES & & & & & & & & & & & & $(-)$ \\
\hline HEPES & & & & & & & & & & & & $(+)$ \\
\hline DIPSO & & & & & & & & & & & & $(-)$ \\
\hline MOBS & & & & & & & & & & & & $(+)$ \\
\hline TAPSO & & & & & & & & & & & & $(-)$ \\
\hline Tris & & & & & & & & & & & & $(-)$ \\
\hline HEPPSO & & & & & & & & & & & & $(+)$ \\
\hline POPSO & & & & & & & & & & & & $(+)$ \\
\hline TEA & & & & & & & & & & & & $(-)$ \\
\hline EPPS & & & & & & & & & & & & $(+)$ \\
\hline Tricine & & & & & & & & & & & & $(-)$ \\
\hline Bicine & & & & & & & & & & & & $(-)$ \\
\hline HEPBS & & & & & & & & & & & & $(+)$ \\
\hline TAPS & & & & & & & & & & & & $(-)$ \\
\hline AMPD & & & & & & & $b$ & & & & $b$ & $(-)$ \\
\hline TABS & & & & & & & & & & & & $(-)$ \\
\hline AMPSO & & & & & & & & & & & & $(-)$ \\
\hline CHES & & & & & & & & & & & & $(+)$ \\
\hline CAPSO & & & & & & & & & & & & $(+)$ \\
\hline AMP & & & & & & & $b$ & $b$ & $b$ & $b$ & $b$ & $(-)$ \\
\hline CAPS & & & & & & & & & & & & $(+)$ \\
\hline CABS & & & & & & & & & & & & $(+)$ \\
\hline
\end{tabular}

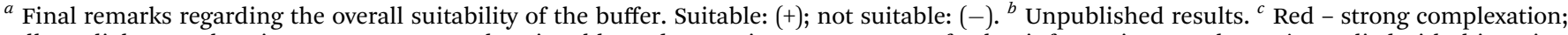
yellow - light complexation; green - no complexation; blue - data not in agreement. For further information, see the ESI $\dagger$ supplied with this review where the complexation models and references are found. 
with some metals, we regard MES as a suitable compound for buffering within its $\mathrm{pH}$ buffer range (5.50-6.70). In a similar way, for PIPES, as previously noted, although complexation is reported, we also regard that in light of the data presented in the literature it is very likely that PIPES does not complex with metal ions, or if it does, complexation occurs to very little extent. Given these reasons, we find PIPES as a possible buffer for use within its $\mathrm{pH}$ buffering range (6.10-7.50). For MOPSO and MOPS, the same arguments as for MES are valid and, therefore, these buffers can be included in our free complexation list, providing an option for $\mathrm{pH}$ between 6.20 to 7.60 and between 6.50 to 7.90 , respectively. By analyzing the literature about HEPES, a similar scenario to that of PIPES is found and, we regard that HEPES is generally described in the literature as a non-complexing buffer and thus suitable to be used in solutions with metal ions. In the case of HEPPSO and $\mathrm{Cu}(\mathrm{II})$, special attention is needed if one wants to use it to buffer $\mathrm{Cu}$ (II) solutions. For EPPS and HEPBS, based on the analyses of the data available, we strongly regard that it does not complex with metals and so, they are possibly good buffers for $\mathrm{pH}$ ranges of 7.30-8.70 and 7.60-9.00 respectively. As for MOBS, POPSO, CAPSO, CAPS, CHES and CABS, for which no or only very faint complexation was described, these can be considered as good buffering agents to be used in solutions containing metal ions. However, these buffers, with the exception of MOBS and POPSO, have a higher buffer range (8.30-11.40), which makes them an option only for specific studies where higher $\mathrm{pH}$ is demanded. Although no stability constants were determined, POPSO was shown to bind with $\mathrm{Cu}$ (II) and therefore, in this particular case, special care is needed.

The buffers reported above are the most adequate for studies free of metal interferences but other buffers are commercialized and may be used as well. Metal-buffer pairs, which form weak complexes, may be used when other components, that have great metal stability constants, are present in solution. In this case, metal interferences from the buffer, due to complexation, are not predictable. Nevertheless, if possible, a speciation study with all elements present in solution should be made in order to ensure such a claim. In other cases, where complex stability constants are lower for the components under study and higher for the metal-buffer complex, speciation studies should be mandatory to ensure a proper conclusion from the data obtained in the work.

\section{Concluding remarks}

Considering all the facts described above and given the large number of stability constants determined for the metal-buffer systems, an imperative need, predicted long time ago by Good, arises: the metal-buffer equilibrium, used in any experiment, should be known and be a key part of the final results and conclusions of the work. In most circumstances, the effects may be negligible, but nevertheless, wrong conclusions may be taken from the results obtained, especially when the stability constants for the metal-buffer are strong. In such cases, two strategies may be adopted: (1) the use of different buffers in individual trials in such a way that differences in the buffer usage may be deduced, if any, or (2) if the use of more than one buffer or running more than one experiment is out of question, the use of a known non-complexing buffer, such as PIPES, HEPES, MES or MOPS, as a buffer agent in the experiments.

To conclude, searching for a proper buffer for a given experiment should be more than just looking for the appropriate buffering $\mathrm{pH}$ range. All other known buffer interactions, such as metal-buffer complexation and biological effects should also be taken into account.

\section{Conflict of interest}

The authors declare that this article content has no conflicts of interest.

\section{Acronyms}

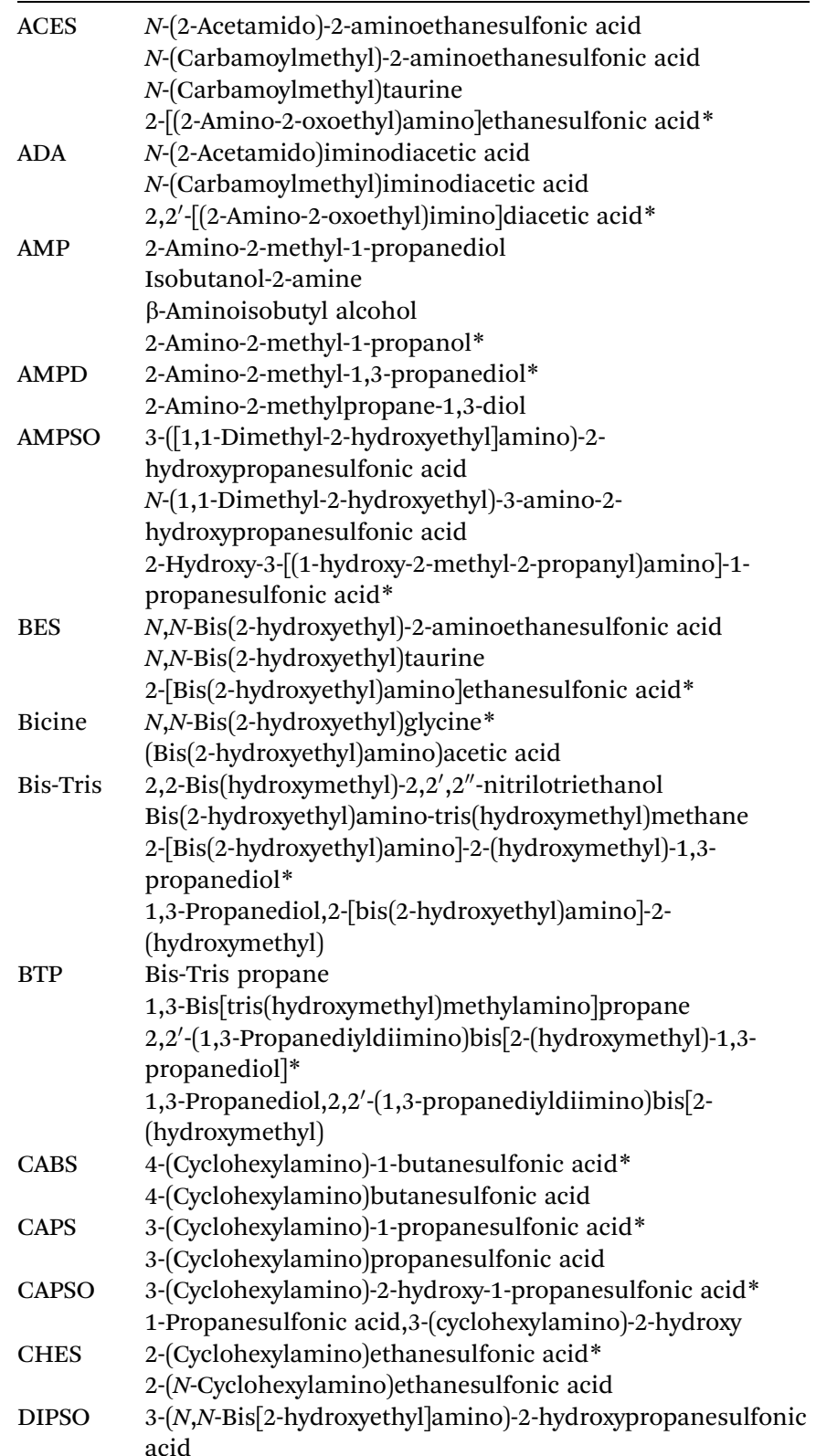


$N, N$-Bis(2-hydroxyethyl)-3-amino-2-hydroxypropanesulfonic acid

3-[Bis(2-hydroxyethyl)amino]-2-hydroxy-1-propanesulfonic acid*

EPPS/ 4-(2-Hydroxyethyl)-1-piperazinepropanesulfonic acid

HEPPS 4-(2-Hydroxyethyl)piperazine-1-propanesulfonic acid $N$-(2-Hydroxyethyl)piperazine- $N N^{\prime}$-(3-propanesulfonic acid) 3-[4-(2-Hydroxyethyl)-1-piperazinyl]-1-propanesulfonic acid* HEPBS $\quad N$-(2-Hydroxyethyl)piperazine- $N N^{\prime}$-(4-butanesulfonic acid) 4-[4-(2-Hydroxyethyl)-1-piperazinyl]-1-butanesulfonic acid* 1-Piperazinebutanesulfonic acid,4-(2-hydroxyethyl)

HEPES 4-(2-Hydroxyethyl)piperazine-1-ethanesulfonic acid $N$-(2-Hydroxyethyl)piperazine- $N{ }^{\prime}$-(2-ethanesulfonic acid) 2-[4-(2-Hydroxyethyl)-1-piperazinyl] ethanesulfonic acid*

HEPPSO $N$-(2-Hydroxyethyl)piperazine- $N^{\prime}$-(2-hydroxypropanesulfonic acid)

4-(2-Hydroxyethyl)piperazine-1-(2-hydroxypropanesulfonic acid)

2-Hydroxy-3-[4-(2-hydroxyethyl)-1-piperazinyl]-1propanesulfonic acid*

MES 2-(N-Morpholino)ethanesulfonic acid 4-Morpholineethanesulfonic acid 2-(4-Morpholinyl)ethanesulfonic acid* 4-( $N$-Morpholino)butanesulfonic acid 4-(4-Morpholinyl)-1-butanesulfonic acid*

\section{MOBS}

MOPS

3-(N-Morpholino)propanesulfonic acid 4-Morpholinepropanesulfonic acid 3-(4-Morpholinyl)-1-propanesulfonic acid*

MOPSO $\quad \beta$-Hydroxy-4-morpholinepropanesulfonic acid 3-Morpholino-2-hydroxypropanesulfonic acid 2-Hydroxy-3-(4-morpholinyl)-1-propanesulfonic acid*

PIPES 1,4-Piperazinediethanesulfonic acid Piperazine-1,4-bis(2-ethanesulfonic acid) Piperazine- $N, N^{\prime}$-bis(2-ethanesulfonic acid) 2,2'-(1,4-Piperazinediyl)diethanesulfonic acid*

POPSO Piperazine-1,4-bis(2-hydroxypropanesulfonic acid) Piperazine- $N, N^{\prime}$-bis(2-hydroxypropanesulfonic acid) 3,3'-(1,4-Piperazinediyl)bis(2-hydroxy-1-propanesulfonic acid)*

TABS $\mathrm{N}$-Tris(hydroxymethyl)methyl-4-aminobutanesulfonic acid 4-\{[1,3-Dihydroxy-2-(hydroxymethyl)-2-propanyl $]$ amino\}-1butanesulfonic acid*

TAPS [(2-Hydroxy-1,1-bis(hydroxymethyl)ethyl)amino]-1propanesulfonic acid $N$-[Tris(hydroxymethyl)methyl]-3-aminopropanesulfonic acid 3-\{[1,3-Dihydroxy-2-(hydroxymethyl)-2-propanyl]amino\}-1propanesulfonic acid*

TAPSO 2-Hydroxy-3-[tris(hydroxymethyl)methylamino]-1propanesulfonic acid $N$-[Tris(hydroxymethyl)methyl]-3-amino-2-

hydroxypropanesulfonic acid

3-\{[1,3-Dihydroxy-2-(hydroxymethyl)-2-propanyl]amino\}-2hydroxy-1-propanesulfonic acid*

TEA

Triethanolamine

Tris(2-hydroxyethyl)amine

$2,2^{\prime}, 2^{\prime \prime}$-Nitrilotriethanol*

TES 2-[(2-Hydroxy-1,1-bis(hydroxymethyl)ethyl)amino] ethanesulfonic acid

$N$-[Tris(hydroxymethyl)methyl]-2-aminoethanesulfonic acid 2-\{[1,3-Dihydroxy-2-(hydroxymethyl)-2-propanyl]amino $\}$ ethanesulfonic acid*

Tricine $\quad N$-[Tris(hydroxymethyl)methyl]glycine $N$-[1,3-Dihydroxy-2-(hydroxymethyl)-2-propanyl]glycine*

Tris
*Systematic name according to IUPAC as described in the online ChemSpider database from the Royal Society of Chemistry. ${ }^{190}$

\section{Acknowledgements}

This work has been supported by Fundação para a Ciência e a Tecnologia (FCT), from the Portuguese Government, through the grants Strategic project-LA23/2013-2014 (IBB) and PEST-C/EQB/ LA0006/2011 (REQUIMTE). Soares EV also thanks the Project "BioInd-Biotechnology and Bioengineering for improved Industrial and Agro-Food processes”, REF. NORTE-07-0124-FEDER000028 Co-funded by the Programa Operacional Regional do Norte (ON.2 - O Novo Norte), QREN, FEDER.

\section{References}

1 W. Wang, H. Yang, X. Wang, J. Jiang and W. Zhu, J. Environ. Sci., 2010, 22, 47-55.

2 K. Nagira, M. Hayashida, M. Shiga, K. Sasamoto, K. Kina, K. Osada, T. Sugahara and H. Murakami, Cytotechnology, 1995, 17, 117-125.

3 M. M. Koerner, L. A. Palacio, J. W. Wright, K. S. Schweitzer, B. D. Ray and H. I. Petrache, Biophys. J., 2011, 101, 362-369.

4 J. K. Grady, N. D. Chasteen and D. C. Harris, Anal. Biochem., 1988, 173, 111-115.

$5 \mathrm{~J}$. S. Blanchard, in Methods in Enzymology, Enzyme Purification and Related Techniques (Part C), ed. W. B. Jakoby, Academic Press, 1984, vol. 104, pp. 404-414.

$6 \mathrm{~W}$. J. Ferguson, K. I. Braunschweiger, W. R. Braunschweiger, J. R. Smith, J. J. McCormick, C. C. Wasmann, N. P. Jarvis, D. H. Bell and N. E. Good, Anal. Biochem., 1980, 104, 300-310.

7 M. Renganathan and S. Bose, Photosynth. Res., 1990, 23, 9599.

8 A. E. Martell and R. M. Smith, NIST Standard Reference Database 46 Version 8.0, NIST Critically Selected Stability Constants of Metal Complexes Database, U.S. Department of Commerce, National Institute of Standards and Technology, Gaithersburg, MD, 2004.

9 D. W. Russell and J. Sambrook, Molecular Cloning: A Laboratory Manual, Cold Spring Harbor Laboratory Press, New York, 3rd edn, 2001.

10 N. E. Good, G. D. Winget, W. Winter, T. N. Connolly, S. Izawa and R. M. M. Singh, Biochemistry, 1966, 5, 467-477.

11 N. E. Good and S. Izawa, Methods Enzymol., 1972, 24, 53-68.

12 H. Wariishi, K. Valli and M. H. Gold, J. Biol. Chem., 1992, 267, 23688-23695.

13 N. M. King, K. M. Elkins and D. J. Nelson, J. Inorg. Biochem., 1999, 76, 175-185.

14 S. Liu and A. D. Hamilton, Bioorg. Med. Chem. Lett., 1997, 7, 1779-1784.

15 T. Thiel, L. Liczkowski and S. T. Bissen, J. Biochem. Biophys. Methods, 1998, 37, 117-129.

16 Buffer Reference Center, Sigma-Aldrich, https:// www.sigmaaldrich.com/life-science/core-bioreagents/biolo- 
gical-buffers/learning-center/buffer-reference-center.html, accessed November 2014.

17 Fisher Scientific - JustPURE “Good” Buffers, http:// www.fishersci.com/ecomm/servlet/cmstatic?storeId $=10652$ \&href=/Scientific/researchAnalytical/ProductsServices/Chemicals/fisher_bioreag_buffers.jsp\#goodbuff, accessed November 2014.

18 VWR International - Chemicals and Laboratory Scientific Supplies, https://us.vwr.com/store/, accessed November 2014.

19 H. M. V. M. Soares, P. C. F. L. Conde, A. A. N. Almeida and M. T. S. D. Vasconcelos, Anal. Chim. Acta, 1999, 394, 325335.

20 H. M. V. M. Soares, S. C. Pinho and M. G. R. T. M. Barros, Electroanalysis, 1999, 11, 1312-1317.

21 H. E. Mash, Y. Chin, L. Sigg, R. Hari and H. Xue, Anal. Chem., 2003, 75, 671-677.

22 Z. M. Anwar and H. A. Azab, J. Chem. Eng. Data, 1999, 44, 1151-1157.

23 H. A. Azab and Z. M. Anwar, J. Chem. Eng. Data, 2012, 57, 2890-2895.

24 D. Wyrzykowski, B. Pilarski, D. Jacewicz and L. Chmurzyński, J. Therm. Anal. Calorim., 2012, 111, 18291836.

25 B. S. Gupta, M. Taha and M. Lee, J. Solution Chem., 2013, 42, 2296-2309.

26 M. Taha, B. S. Gupta and M. Lee, J. Chem. Eng. Data, 2011, 56, 3541-3551.

27 R. B. Johnston and P. C. Singer, Chemosphere, 2007, 69, 517525.

28 R. Ginocchio, L. M. De la Fuente, P. Sánchez, E. Bustamante, Y. Silva, P. Urrestarazu and P. H. Rodríguez, Environ. Toxicol. Chem., 2009, 28, 20692081.

29 D. Aguilar, J. Galceran, E. Companys, J. Puy, C. Parat, L. Authier and M. Potin-Gautier, Phys. Chem. Chem. Phys., 2013, 15, 17510-17521.

30 R. F. Carbonaro and A. T. Stone, Anal. Chem., 2005, 77, 155164.

31 M. T. S. D. Vasconcelos and C. M. R. Almeida, Anal. Chim. Acta, 1998, 369, 115-122.

32 M. T. S. D. Vasconcelos, M. A. Azenha and C. M. R. Almeida, Anal. Biochem., 1998, 265, 193-201.

33 H. M. V. M. Soares and P. C. F. L. Conde, Anal. Chim. Acta, 2000, 421, 103-111.

34 D. R. Hoffman, J. L. Okon and T. R. Sandrin, Chemosphere, 2005, 59, 919-927.

35 Y. Ito, N. Satoh, T. Ishii, J. Kumakura and T. Hirano, Clin. Chim. Acta, 2014, 427, 86-93.

36 M. Sokołowska and W. Bal, J. Inorg. Biochem., 2005, 99, 1653-1660.

37 Z. M. Anwar, J. Chin. Chem. Soc., 2005, 52, 863-871.

38 Q. Yu, A. Kandegedara, Y. Xu and D. B. Rorabacher, Anal. Biochem., 1997, 253, 50-56.

39 M. Brom, L. Joosten, W. J. Oyen, M. Gotthardt and O. C. Boerman, EJNMMI Res., 2012, 2, 4.
$40 \mathrm{H}$. M. V. M. Soares and M. G. R. T. M. Barros, Electroanalysis, 2001, 13, 325-331.

41 C. M. M. Machado, G. M. S. Alves, I. S. S. Pinto, S. Scheerlinck, S. Van Acker and H. M. V. M. Soares, J. Solution Chem., 2013, 42, 1602-1619.

42 M. Eliat-Eliat, I. S. S. Pinto, G. M. S. Alves, V. Olle and H. M. V. M. Soares, J. Coord. Chem., 2013, 66, 3544-3560.

43 C. M. M. Machado, P. Gameiro and H. M. V. M. Soares, J. Solution Chem., 2008, 37, 603-617.

44 K. H. Scheller, T. H. J. Abel, P. E. Polanyi, P. K. Wenk, B. E. Fischer and H. Sigel, Eur. J. Biochem., 1980, 107, 455-466.

45 H. Sigel, K. H. Scheller and B. Prijs, Inorg. Chim. Acta, 1982, 66, 147-155.

46 S. M. Sadeghi, C. M. H. Ferreira, S. Vandenbogaerde and H. M. V. M. Soares, J. Coord. Chem., 2015, 68, 777-793.

47 M. M. Khalil and M. Taha, Monatshefte für Chemie Chem. Mon., 2004, 135, 385-395.

48 H. A. Azab and A. M. El-Nady, Monatshefte für Chemie Chem. Mon., 1994, 125, 849-858.

49 C. M. M. Machado and H. M. V. M. Soares, Talanta, 2003, 71, 1352-1363.

50 C. M. M. Machado, I. Cukrowski and H. M. V. M. Soares, Talanta, 2006, 68, 819-830.

51 C. M. M. Machado, I. Cukrowski and H. M. V. M. Soares, Electroanalysis, 2005, 17, 1291-1301.

52 H. A. Azab, F. S. Deghaidy, A. S. Orabi and N. Y. Farid, J. Chem. Eng. Data, 2000, 45, 709-715.

53 C. M. H. Ferreira, I. S. S. Pinto, A. Amoresano, S. M. Sadeghi and H. M. V. M. Soares, J. Coord. Chem., 2014, 67, 33543370.

54 T. Laureys, I. S. S. Pinto, C. V. M. Soares, H. B. Boppudi and H. M. V. M. Soares, J. Chem. Eng. Data, 2012, 57, 87-92.

55 C. M. M. Machado and H. M. V. M. Soares, Talanta, 2007, 71, 1352-1363.

56 C. M. M. Machado, O. Victoor and H. M. V. M. Soares, Talanta, 2007, 71, 1326-1332.

57 M. Muzikár, J. Havel and M. Macka, Electrophoresis, 2002, 23, 1796-1802.

58 B. E. Fischer, U. K. Häring, R. Tribolet and H. Sigel, Eur. J. Biochem., 1979, 94, 523-530.

59 I. Zawisza, M. Rózga, J. Poznański and W. Bal, J. Inorg. Biochem., 2013, 129, 58-61.

60 R. W. Peters, J. Hazard. Mater., 1999, 66, 151-210.

61 T.-C. Chen and A. Hong, J. Hazard. Mater., 1995, 41, 147160.

62 C. M. M. Machado, I. Cukrowski and H. M. V. M. Soares, Helv. Chim. Acta, 2003, 86, 3288-3304.

63 M. Taha, R. A. Saqr and A. T. Ahmed, J. Chem. Thermodyn., 2007, 39, 304-308.

64 H. A. Azab, A. S. Orabi and E.-S. E. T. Abd, J. Chem. Eng. Data, 2001, 46, 346-354.

65 C. M. M. Machado, I. Cukrowski and H. M. V. M. Soares, Electroanalysis, 2006, 18, 719-729.

66 H. A. Azab, S. S. Al-Deyab, Z. M. Anwar, I. I. Abd El-Gawad and R. M. Kamel, J. Chem. Eng. Data, 2011, 56, 2613-2625. 
67 A. S. Orabi, H. A. Azab, F. Saad and H. Said, J. Solution Chem., 2010, 39, 319-334.

68 O. M. El-Roudi, E. M. Abd Alla and S. A. Ibrahim, J. Chem. Eng. Data, 1997, 42, 609-613.

69 M. A. El-Gahami, A. S. Al-Bogami and H. M. Albishri, J. Mol. Liq., 2014, 193, 45-50.

70 M. A. El-Gahami and H. M. Albishri, J. Solution Chem., 2013, 42, 2012-2024.

71 E. Csuhai, A. Safavi and L. B. Hersh, Biochemistry, 1995, 34, 12411-12419.

72 Y. Fujita, T. Tokunaga and H. Kataoka, Anal. Biochem., 2011, 409, 46-53.

73 T. M. Pabst, G. Carta, N. Ramasubramanyan, A. K. Hunter, P. Mensah and M. E. Gustafson, Biotechnol. Prog., 2008, 24, 1096-1106.

74 F.-K. Liu, J. Chromatogr. A, 2009, 1216, 2554-2559.

75 P. G. Righetti, S. Magnusdottir, C. Gelfi and M. Perduca, J. Chromatogr. A, 2001, 920, 309-316.

76 T.-H. Chang, F.-K. Liu, Y.-C. Chang and T.-C. Chu, Chromatographia, 2008, 67, 723-730.

77 M. Beneš, M. Riesová, J. Svobodová, E. Tesařová, P. Dubský and B. Gaš, Anal. Chem., 2013, 85, 8526-8534.

78 M. Riesová, J. Svobodová, Z. Tošner, M. Beneš, E. Tesařová and B. Gaš, Anal. Chem., 2013, 85, 8518-8525.

79 L. Zhang, D. Duan, X. Cui, J. Sun and J. Fang, Tetrahedron, 2013, 69, 15-21.

80 J. I. Kliegman, S. L. Griner, J. D. Helmann, R. G. Brennan and A. Glasfeld, Biochemistry, 2006, 45, 3493-3505.

81 S. Striegler, N. A. Dunaway, M. G. Gichinga, J. D. Barnett and A.-G. D. Nelson, Inorg. Chem., 2010, 49, 2639-2648.

82 D. Long and D. Yang, Biophys. J., 2009, 96, 1482-1488.

83 E. V. Soares, A. P. R. S. Duarte and H. M. V. M. Soares, Chem. Speciation Bioavailability, 2000, 12, 59-65.

84 O. M. Lage, M. T. S. D. Vasconcelos, H. M. V. M. Soares, J. M. Osswald, F. Sansonetty, A. M. Parente and R. Salema, Arch. Environ. Contam. Toxicol., 1996, 31, 199205.

85 K. I. Keating, P. B. Caffrey and B. C. Dagbusan, Environ. Toxicol. Chem., 1996, 15, 348-352.

86 D. E. Parfitt, A. A. Almehdi and L. N. Bloksberg, Sci. Hortic., 1988, 36, 157-163.

87 G. J. de Klerk, J. Hanecakova and J. Jásik, Plant Cell, Tissue Organ Cult., 2008, 95, 285-292.

88 P. H. Edelstein and M. A. C. Edelstein, J. Clin. Microbiol., 1993, 31, 3329-3330.

89 K. Tsuchiya, A. Ideta, Y. Nishimiya, S. Tsuda and Y. Aoyagi, Reprod., Fertil. Dev., 2014, 26, 139.

90 A. I. Cowan and R. L. Martin, Brain Res., 1996, 717, 69-75.

91 P. M. A. van Haaren, E. VanBavel, H. Vink and J. A. E. Spaan, Am. J. Physiol.: Heart Circ. Physiol., 2005, 289, H2503-H2507.

92 C. G. Bevans and A. L. Harris, J. Biol. Chem., 1999, 274, 3711-3719.

93 M. Taha, B. S. Gupta, I. Khoiroh and M. Lee, Macromolecules, 2011, 44, 8575-8589.

94 M. A. Metrick, J. E. Temple and G. Macdonald, Biophys. Chem., 2013, 184, 29-36.
95 W. A. Lubas and R. G. Spiro, J. Biol. Chem., 1988, 263, 39903998.

96 D. E. Garfin, in Methods in Enzymology, Guide to protein purification, ed. P. M. Deutsche, Academic Press, San Diego, 1990, pp. 425-441.

97 K. J. Davies and A. L. Goldberg, J. Biol. Chem., 1987, 262, 8227-8234.

98 J. Olert, K. H. Wiedorn, T. Goldmann, H. Kühl, Y. Mehraein, H. Scherthan, F. Niketeghad, E. Vollmer, A. M. Müller and J. Müller-Navia, Pathol., Res. Pract., 2001, 197, 823-826.

99 K. H. Wiedorn, J. Olert, R. A. P. Stacy, T. Goldmann, H. Kühl, J. Matthus, E. Vollmer and A. Bosse, Pathol., Res. Pract., 2002, 198, 735-740.

100 C. J. Fowler, B. A. Callingham and M. D. Houslay, J. Pharm. Pharmacol., 1977, 29, 411-415.

101 V. Virtanen and G. Bordin, Anal. Chim. Acta, 1999, 402, 5966.

102 N. C. Stellwagen, A. Bossi, C. Gelfi and P. G. Righetti, Anal. Biochem., 2000, 287, 167-175.

103 J. R. Wenner and V. A. Bloomfield, Anal. Biochem., 1999, 212, 201-212.

104 A. T. Palasz, P. B. Breña, J. De la Fuente and A. GutiérrezAdán, Theriogenology, 2008, 70, 1461-1470.

105 K. Wilson and J. M. Walker, Principles and Techniques of Practical Biochemistry, Cambridge University Press, Cambridge, 5th edn, 2000.

106 V. S. Stoll and J. S. Blanchard, in Methods in Enzymology, Guide to Protein Purification, ed. M. p. Deutscher, Academic Press, 1990, pp. 24-38.

107 G. Zhao and N. D. Chasteen, Anal. Biochem., 2006, 349, 262267.

108 X. Yang and N. D. Chasteen, Biochem. J., 1999, 618, 615-618.

109 C. J. Baker, N. M. Mock, D. P. Roberts, K. L. Deahl, C. J. Hapeman, W. F. Schmidt and J. Kochansky, Free Radical Biol. Med., 2007, 43, 1322-1327.

110 H. J. Grande and K. R. van der Ploeg, FEBS Lett., 1978, 95, 352-356.

111 S. Heinisch and J. L. Rocca, J. Chromatogr. A, 2004, 1048, 183-193.

112 E. M. Borges and C. H. Collins, J. Chromatogr. A, 2012, 1227, $174-180$

113 K. D. Altria, N. W. Smith and C. H. Turnbull, J. Chromatogr. B: Biomed. Sci. Appl., 1998, 717, 341-353.

114 J. Jiskra, T. Jiang, H. A. Claessens and C. A. Cramers, J. Microcolumn Sep., 2000, 12, 530-540.

115 F. Wang, C. Chmil, F. Pierce, K. Ganapathy, B. B. Gump, J. A. MacKenzie, Y. Metchref and K. Bendinskas, J. Chromatogr. B: Anal. Technol. Biomed. Life Sci., 2013, 934, 26-33.

116 T. Minami, H. Matsubara, M. O-Higashi, N. Otaki, M. Kimura, K. Kubo, N. Okabe and Y. Okazaki, J. Chromatogr. B: Biomed. Sci. Appl., 1996, 685, 353-359.

117 D. Wyrzykowski, J. Czupryniak, T. Ossowski and L. Chmurzyński, J. Therm. Anal. Calorim., 2010, 102, 149154.

118 S. Nakano, Y. Matumoto and M. Yoshii, Talanta, 2005, 68, 312-317. 
119 K. E. S. Dean, G. Klein, O. Renaudet and J.-L. Reymond, Bioorg. Med. Chem. Lett., 2003, 13, 1653-1656.

120 L. Yu and C. Yu, Biochim. Biophys. Acta, 1980, 593, 24-38.

121 E. Z. Jahromi, W. White, Q. Wu, R. Yamdagni and J. Gailer, Met. Integr. Biometal Sci., 2010, 2, 460-468.

122 J. S. Magyar and H. A. Godwin, Anal. Biochem., 2003, 320, 39-54.

123 M. Amar, F. Perin-Dureau and J. Neyton, Biophys. J., 2001, 81, 107-116.

124 A. Fayyazuddin, A. Villarroel, A. Le Goff, J. Lerma and J. Neyton, Neuron, 2000, 25, 683-694.

125 S. L. Sensi, D. Ton-That, J. H. Weiss, A. Rothe and K. R. Gee, Cell Calcium, 2003, 34, 281-284.

126 W. T. Jenkins, Arch. Biochem. Biophys., 1994, 313, 89-95.

127 L. L. Thio and H. X. Zhang, Neuroscience, 2006, 139, 13151327.

128 J. E. Stelzer, D. P. Fitzsimons and R. L. Moss, Biophys. J., 2006, 90, 4119-4127.

129 A. Atkinson and A. G. Lowe, Biochim. Biophys. Acta, Biomembr., 1972, 266, 103-115.

130 S. Bayen, I. Worms, N. Parthasarathy, K. Wilkinson and J. Buffle, Anal. Chim. Acta, 2006, 575, 267-273.

131 T. Ono, A. Rompel, H. Mino and N. Chiba, Biophys. J., 2001, 81, 1831-1840.

132 R. W. Wheatley, J. C. Kappelhoff, J. N. Hahn, M. L. Dugdale, M. J. Dutkoski, S. D. Tamman, M. E. Fraser and R. E. Huber, Arch. Biochem. Biophys., 2012, 521, 51-61.

133 T. J. Beeler, K. S. Gable and J. M. Keffer, Biochim. Biophys. Acta, 1983, 734, 221-234.

134 T. Brittain, J. Inorg. Biochem., 2000, 81, 99-103.

135 S. M. Kapetanaki, S. J. Field, R. J. L. Hughes, N. J. Watmough, U. Liebl and M. H. Vos, Biochim. Biophys. Acta, Bioenerg., 2008, 1777, 919-924.

136 N. Shibayama, H. Morimoto and T. Kitagawa, J. Mol. Biol., 1986, 192, 331-336.

137 J. A. Dohm, M.-H. Hsu, J.-R. Hwu, R. C. C. Huang, E. N. Moudrianakis, E. E. Lattman and A. G. Gittis, J. Mol. Biol., 2005, 349, 731-744.

138 M. Elrod-Erickson, T. E. Benson and C. O. Pabo, Structure, 1998, 6, 451-464.

139 L. W. Neuteboom, B. I. Lindhout, I. L. Saman, P. J. J. Hooykaas and B. J. van der Zaal, Biochem. Biophys. Res. Commun., 2006, 339, 263-370.

140 G. P. Richards, C. H. Hammer, M. K. Garfield and S. Parveen, Biochim. Biophys. Acta, 2004, 1700, 219-229.

141 S. V. Antonyuk, R. W. Strange, S. L. Marklund and S. S. Hasnain, J. Mol. Biol., 2009, 388, 310-326.

142 E. Bastiaensen and W. De Potter, FEBS Lett., 1989, 244, 477480.

143 Q. Wang, E. Leino, A. Jancsó, I. Szilıgyi and T. Gajda, ChemBioChem, 2008, 9, 1739-1748.

144 K. Abdi, H. Hadadzadeh, M. Salimi, J. Simpson and A. D. Khalaji, Polyhedron, 2012, 44, 101-112.

145 L. Tušek-Božić, F. Frausin, V. Scarcia and A. Furlani, J. Inorg. Biochem., 2003, 95, 259-269.

146 S. Juillard, A. Bondon and G. Simonneaux, J. Inorg. Biochem., 2006, 100, 1441-1448.
147 Y. Seto, H. Ohkuma, S. Takayasu, T. Iba, A. Umeda and K. Abe, Anal. Chim. Acta, 2001, 429, 19-26.

148 J. Ejnik, J. Robinson, J. Zhu, H. Försterling, C. F. Shaw and D. H. Petering, J. Inorg. Biochem., 2002, 88, 144-152.

149 K. Kanaori, D. Ohta and A. Y. Nosaka, FEBS Lett., 1997, 412, 301-304.

150 F. A. L. J. Peters, R. Van Spanning and R. Kraayenhof, Biochim. Biophys. Acta, 1983, 724, 159-165.

151 C. Van Der Drift and G. D. Vogels, Biochim. Biophys. Acta, Enzymol., 1970, 198, 339-352.

152 S. A. Mohamed, H. M. Abdel-Mageed, S. A. Tayel, M. A. ElNabrawi and A. S. Fahmy, Process Biochem., 2011, 46, 642648.

153 H. Pesliakas, V. Zutautas and B. Baskeviciute, J. Chromatogr. A, 1994, 678, 25-34.

154 F. C. Meldrum, T. Douglas, S. Levi, P. Arosio and S. Mann, J. Inorg. Biochem., 1995, 58, 59-68.

155 J. L. Fisher, Neuropharmacology, 2002, 42, 922-928.

156 E. A. Permyakov, D. B. Veprintsev, G. Y. Deikus, S. E. Permyakov, L. P. Kalinichenko, V. M. Grishchenko and C. L. Brooks, FEBS Lett., 1997, 405, 273-276.

157 C. Fauquant, R. E. M. Diederix, A. Rodrigue, C. Dian, U. Kapp, L. Terradot, M.-A. Mandrand-Berthelot and I. Michaud-Soret, Biochimie, 2006, 88, 1693-1705.

158 A. Martelli and J.-M. Moulis, J. Inorg. Biochem., 2004, 98, 1413-1420.

159 H. Böhme and B. Schrautemeier, Biochim. Biophys. Acta, 1987, 891, 1-7.

160 E. Chekmeneva, R. Prohens, J. M. Díaz-Cruz, C. Ariño and M. Esteban, Anal. Biochem., 2008, 375, 82-89.

161 Y. Seo, K. Satoh, K. Watanabe, H. Morita, A. Takamata, T. Ogino and M. Murakami, Magn. Reson. Med., 2011, 65, 1005-1012.

162 E. M. Leonard, L. M. Pierce, P. L. Gillis, C. M. Wood and M. J. O'Donnell, Aquat. Toxicol., 2009, 92, 179-186.

163 K. A. C. De Schamphelaere, D. G. Heijerick and C. R. Janssen, Ecotoxicology, 2004, 13, 697-705.

164 M. A. Will, N. A. Clark and J. E. Swain, J. Assist. Reprod. Genet., 2011, 28, 711-724.

165 K. L. Plathe, S.-W. Lee, B. M. Tebo, J. R. Bargar and R. Bernier-Latmani, Environ. Sci. Technol., 2013, 47, 36063613.

166 T. C. Zhang and Y. H. Huang, J. Environ. Eng., 2005, 131, 461-470.

167 J. T. Fletcher, B. S. Bruck and D. E. Deever, Tetrahedron Lett., 2013, 54, 5366-5369.

168 H. Hasegawa, I. M. M. Rahman, M. Nakano, Z. A. Begum, Y. Egawa, T. Maki, Y. Furusho and S. Mizutani, Water Res., 2011, 45, 4844-4854.

169 S. Fujii, H. Itoh, A. Yoshida, S. Higashi, H. Ikezawa and K. Ikeda, Arch. Biochem. Biophys., 2005, 436, 227-236.

170 R. Flouty and G. Estephane, J. Environ. Manage., 2012, 111, 106-114.

171 K. Kabała, M. Janicka-Russak, M. Burzyński and G. Kłobus, J. Plant Physiol., 2008, 165, 278-288.

172 M. D. Machado, E. V. Soares and H. M. V. M. Soares, J. Hazard. Mater., 2010, 180, 347-353. 
173 J. Vanden Bussche and E. V. Soares, Appl. Microbiol. Biotechnol., 2011, 90, 679-687.

174 W. D. Schecher and D. C. McAvoy, MINEQL+ A chemical Equilibrium Modeling System, Version 4.5. for Windows. User's Manual, Hallowell, Maine, 2003.

175 E. Jankowska, M. Blaszak and T. Kowalik-Jankowska, J. Inorg. Biochem., 2013, 121, 1-9.

176 S. Jovanović, B. Petrović, Ž. D. Bugarčić and R. van Eldik, Dalton Trans., 2013, 42, 8890-8896.

177 L. B. Kuntze, R. C. Antonio, T. C. Izidoro-Toledo, C. A. Meschiari, J. E. Tanus-Santos and R. F. Gerlach, Basic Clin. Pharmacol. Toxicol., 2014, 114, 233-239.

178 D. Mayweather, K. Danyal, D. R. Dean, L. C. Seefeldt and B. M. Hoffman, Biochemistry, 2012, 51, 8391-8398.

179 L. A. Schurig-briccio and R. B. Gennis, J. Bacteriol., 2012, 194, 4107-4113.

180 M. E. Mamprin, S. Petrocelli, E. Guibert and J. Rodríguez, CryoLetters, 2008, 29, 121-133.

181 C. P. Keller and E. Van Volkenburgh, Plant Physiol., 1996, 110, 1007-1016.
182 P. J. Millard, B. L. Roth, H. P. Thi, S. T. Yue and R. P. Haugland, Appl. Environ. Microbiol., 1997, 63, 28972905.

183 M. T. S. D. Vasconcelos, C. M. R. Almeida, O. Lage and F. Sansonetty, Environ. Toxicol. Chem., 2000, 19, 2542-2550.

184 E. V. Soares, A. P. R. S. Duarte, R. A. Boaventura and H. M. V. M. Soares, Appl. Microbiol. Biotechnol., 2002, 58, 836-841.

185 E. V. Soares, K. Hebbelinck and H. M. V. M. Soares, Can. J. Microbiol., 2003, 49, 336-343.

186 C. A. Sousa and E. V. Soares, Appl. Microbiol. Biotechnol., 2014, 98, 5153-5160.

187 M. D. Machado, S. Janssens, H. M. V. M. Soares and E. V. Soares, J. Appl. Microbiol., 2009, 106, 1792-1804.

188 M. D. Machado, M. S. F. Santos, C. Gouveia, H. M. V. M. Soares and E. V. Soares, Bioresour. Technol., 2008, 99, 2107-2115.

189 M. Kanematsu, T. M. Young, D. A. Sverjensky, P. G. Green and J. L. Darby, Environ. Sci. Technol., 2011, 45, 561-568.

190 http://www.chemspider.com/. 